Une étude canadienne récente sur les possibilités d'emploi dans différents secteurs pour la période allant de 2010 à 2020 démontre que les possibilités d’emploi pour les travailleurs forestiers, les techniciens et les technologistes forestiers connaitraient une croissance de $5 \%$ et que les emplois pour les professionnels de la foresterie augmenteraient de $17 \%$ au cours de la même période. Cette croissance prévue ainsi le profil démographique des travailleurs actuellement en poste devraient inciter les récents diplômés sorienter dans le secteur. Une autre étude réalisée en 2012 en Ontario souligne que $100 \%$ des professionnels de la foresterie occupait un emploi deux ans après la fin de leurs études. Le seul autre domaine compa- rable est la médecine dentaire. Enfin, McLean's a publié un article sur les emplois de l'avenir au Canada et a établi un pourcentage des postes qui seraient non comblés au cours des dix prochaines années. Les trois catégories du secteur forestier qu'ils ont étudiées laissaient entrevoir des postes vacants dans des proportions allant de $27 \%$ à $100 \%$, la dernière portant sur les contremaîtres de l'exploitation et des travaux forestiers.

En résumé, le secteur forestier semble être sur le point de connaitre un nouveau départ qui entraînera la création d'emplois pour les professionnels et les techniciens de la foresterie, les biologistes, les gestionnaires de lenvironnement et pour plusieurs autres spécialistes du domaine. L'industrie demeure un élément essentiel de l'économie canadienne et nous sommes les chefs de file en matière de normes environnementales. Nous avons accès à un approvisionnement en matière ligneuse qui peut répondre aux demandes croissantes; il y aura une variété d'emploi nécessitant des aptitudes diverses d'un océan à l'autre et il aura également des boums régionaux. La mobilité constituera un avantage lorsqu'il sera question de chercher un emploi, ainsi qu'un ensemble solide de compétences personnelles et une formation technique reconnue. Il me semble que le phénix est sur le point de prendre à nouveau son envol.

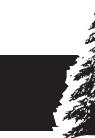 at m

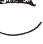 \\ If A Tree is Sold in the Forest, How Do You Write About It}

\title{
In the Power of the Government - The Rise and Fall of Newsprint in Ontario
}

Reconsidering the History of GovernmentIndustry Relations in Our Woodlands

n general, historians who have examined relations between Canada's politicians and the country's forest companies have argued that the former did all they could to ensure the latter's prosperity. This often involved providing access to Crown timber and water powers on remarkably favourable terms and at prices that were well below market value. Although public revenues suffered as a result, fostering the strongest possible industry-so the argument goes-was the government's overriding goal.

There are ample grounds for reconsidering this standing view of government-industry relations in our woodlands, however. The evidence indicates that the story has often been much more nuanced than the traditional one of "politicians selling out to business". There are many reasons for re-evaluating our understanding of this subject, one of which has to do with exploring more carefully the very trees that industry used in its operations. The result of engaging in this process is the realization that elected officials often rebuffed the domestic pulp and paper makers' demands for resources, and often for confounding reasons.

This tale will be told using northern Ontario as the setting, with the pulp and paper mill in Espanola serving as the centre of the story. This enterprise came into existence as a result of the efforts of pioneer Canadian paper-maker and Member of Provincial Parliament John R. Barber and his associates. At the turn of the twentieth century, they hatched a plan to construct a mill just upstream from the mouth of the Spanish River. At this location on the waterway they had secured freehold rights to develop the water power, and the site would soon become the town of Espanola. They also acquired from the Ontario government a lease to the pulpwood on the Spanish River watershed, and by 1902 their enterprise was producing pulp. Although a number of factors prevented the operation from expanding to a fullyintegrated paper-making facility, it continued to operate over the next decade.

The mill's fortunes would enjoy a decided uptick in the early 1910s. At that time, iconic American papermaker George H. Mead took the helm of the mills in Espanola and nearby Sault Ste. Marie and Sturgeon Falls and merged them into the new Spanish River Pulp and Paper Mills Company. Not only did he turn it into one of the most progressive firms in the industry, he dramatically expanded its productive capacity. This included adding a 200ton newsprint-making line to the mill in Espanola on the eve of the First World War, an augmentation that contributed to Spanish River becoming Canada's largest newsprint producer in the wake of the conflict.

While dramatically increasing the company's efficiency and productive capacity represented boons for the communities in which its mills were located, achieving these aims also created challenges for Spanish River. Manufacturing much more newsprint per day concomi- 


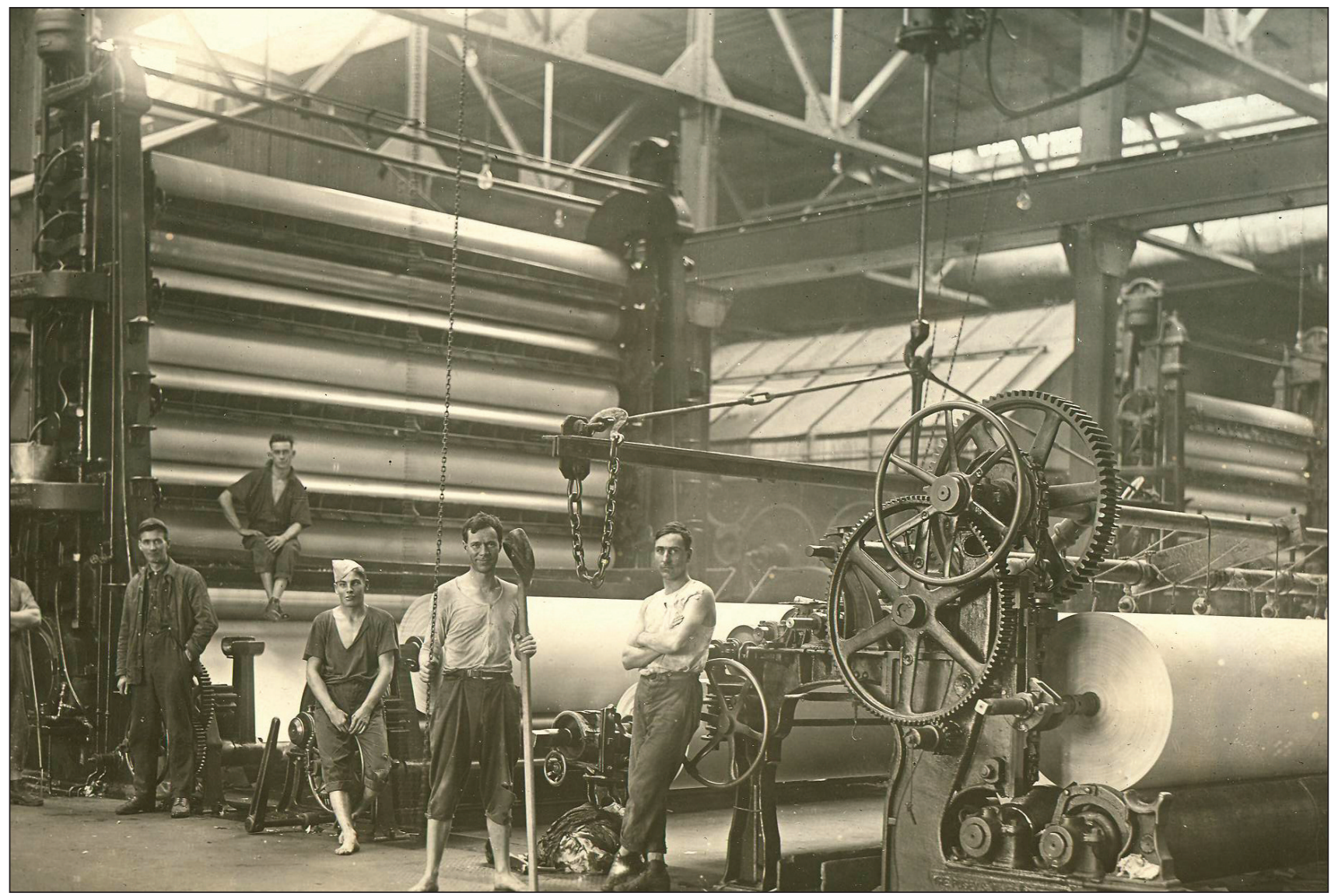

George H. Mead pushed Spanish River to become Canada's leading producer of newsprint just after the First World War. This photograph illustrates some of the men who worked inside the company's mills; those without shoes went barefoot in an effort to maximize their traction on the plant's wet and slippery floor.

tantly increased exponentially its demand for fibre, a situation that was exacerbated by several other factors. Spanish River's three mills were the first to have been built in northern Ontario, and by the mid-1910s they had thus been harvesting their woodlands for the better part of a decade and a half; they had exhausted their most accessible stands of spruce and were now cutting in some instances-a few hundred miles away from their paper plants. In addition, this harvesting activity had revealed that the timber limits the firm leased from the Ontario government were large in size but deficient in terms of spruce, the species upon which the manufacture of newsprint depended at the time. This grim reality was confirmed by an outside consultant Spanish River had hired to investigate its woodlands during the war, and the report from that study estimated that the firm's supply of spruce would last, at most, another half dozen years.
Spanish River took several approaches to addressing this challenge. The firm had already hired a professional forester to improve how it managed its timber limits. A few years after the war, the company would formally commit to managing its woodlands on a sustained yield basis.

The company also sought the Ontario government's help in dealing with its looming fibre shortage. The timber limit that its mill in Espanola leased was largely within the Great Lakes-St. Lawrence Forest Region, a zone within which spruce was not the dominant species, but north of this tract lay the spruce-rich boreal forest. And so, in September 1919 Spanish River formally applied for a roughly 4000 square mile swath of pulpwood to the northwest of the area it had originally leased from the provincial Conservatives, who were in power at the time. In exchange, the firm offered to raise its mill capacity to over 300 tons per day, an augmentation project it immediately undertook.

G. Howard Ferguson, the Tories' Minister of Lands and Forests and someone whom historians have portrayed as having been the Ontario pulp and paper industry's greatest advocate, responded to Spanish River's request for Crown timer with enthusiastic words but little in the way of action. Yes, Ferguson definitely agreed that the mill in Espanola had but "a very few years" worth of spruce remaining on its existing pulpwood concession, but he refused to grant the new limit to Spanish River. Instead, he promised to "reserve" the tract for Spanish River, and thereafter the area became known as the "Spanish Reserve".

It is here where historical accounts have stopped chronicling this affair. As a result, they have depicted Ferguson's pledge to the company as tantamount to him having granted it this pulpwood limit. And this portrayal of the minister 


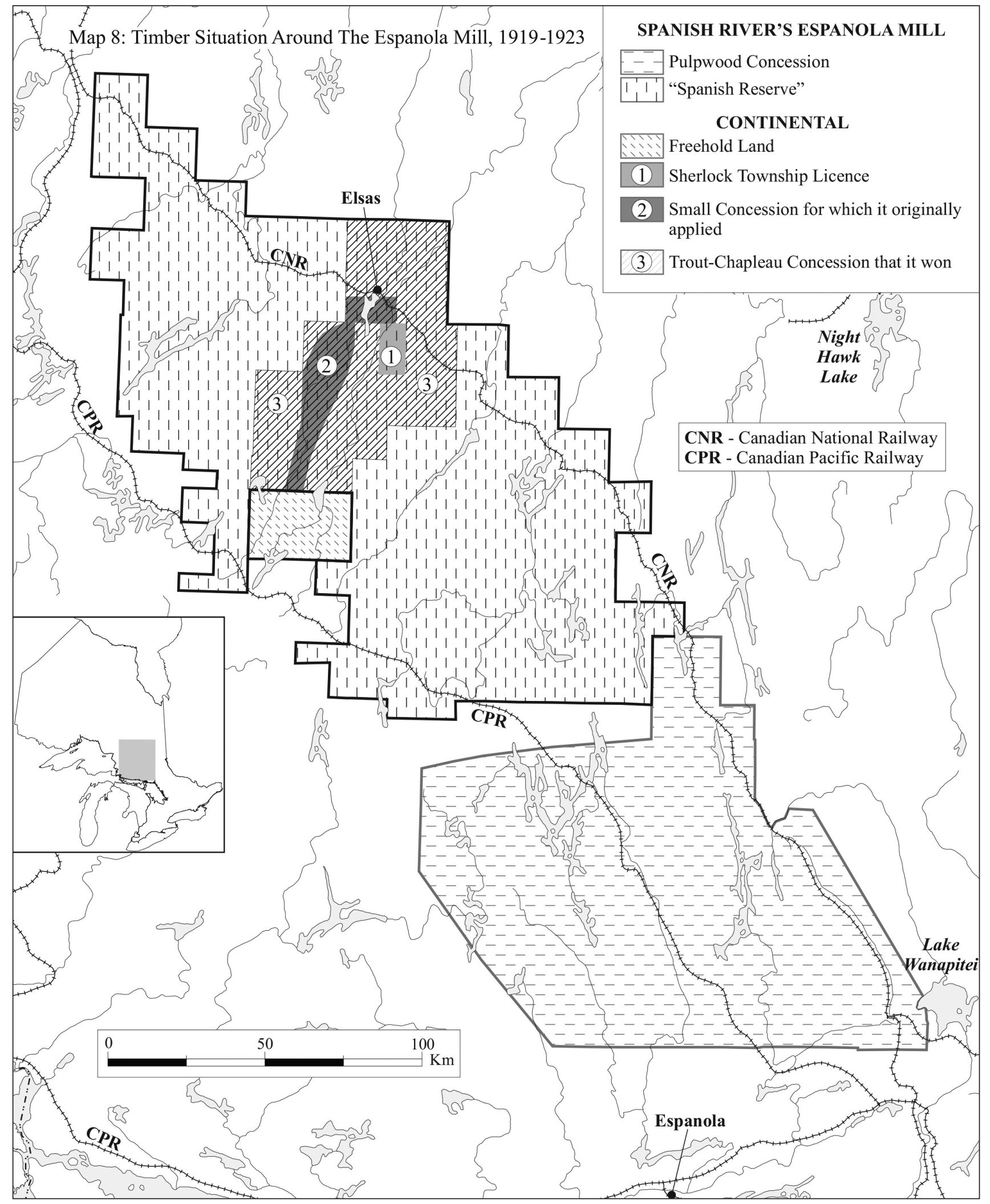

Pulpwood Situation North of Espanola, 1919-1923 (Map by Leo Lariviere, Laurentian University) 
has been used as further evidence of his unabashed commitment to doing all he could to support newsprint makers.

Telling "the rest of the story", as Paul Harvey used to say, however, provides a very different picture of what this incident represents. For in 1919, Ferguson's Tories were turfed from office, and the party that seized power-the United Farmers of Ontario (UFO)-was bound and determined to ruin Ferguson. It attempted to realize this goal by launching a Royal Commission into the Conservatives' handling of Crown timber, an inquiry that had Ferguson squarely in its cross-hairs. For the longest time, as revelations of his illegal timber dealings made headlines across the province, it appeared that his political career would be over and that he might even be subject to criminal prosecution.

But then the erstwhile minister made a Phoenix-like recovery by turning the tables on the UFO government. He depicted it as living in a glass house and throwing stones because it had recently signed a deal with an American timber baron that Ferguson depicted as having been a complete sell out to the Yankee industrialist. Moreover, while he was on the stand Ferguson revealed his promise to reserve the area for Spanish River's mill in Espanola and portrayed it as representing a huge gift to industry. So, too, did the UFO's newspaper, thereby leaving the governing party in a real pickle. The Farmers knew that Spanish River desperately needed this supplementary supply of pulpwood, but it could not simply hand it over to the company because doing so would leave it guilty of the same corrupt practices for which it was excoriating Ferguson.

In the meantime, a new actor appeared on the scene, one that previous accounts of Ontario's pulp and paper industry have essentially ignored. The International Paper Company (IP) had been born on the eve of the twentieth century out of a mega-merger of roughly twenty newsprint mills located in the northeastern United States. Virtually overnight it became the world's largest producer. By this time the managers of some of its plants had already recognized that their local supplies of spruce were rapidly diminishing. As a result, they had begun creating subsidiary firms through which they aggressively acquired huge tracts of pulpwood in eastern Canada, including northern Ontario.

In the wake of the First World War, IP had set up shop in the back yard of its most eminent Canadian competitor, namely Spanish River. IP acquired nearly 50000 acres of land grants near Chapleau (roughly 200 miles northwest of Espanola) and created a new firm in Ontario, Continental Wood Products, whose name was derived from Continental Paper and Bag Mills, one of IP's American subsidiaries. Continental Wood immediately began exporting the spruce from this territory to its mills in the US and rechristened its base of operations Elsas to honour Continental Paper's president.

It quickly aimed to expand the scope of its operations. In 1922, Continental Wood made a proposal to the reigning Farmers government. In exchange for constructing a small kraft pulp mill in Elsas, the firm asked for a lease to a roughly 200-square mile tract of pulpwood upriver from the town. Apparently, the UFO was smitten by this idea. The Farmers' Minister of Lands and Forests, Beniah Bowman, actually coached Continental in how to re-write its application for Crown timber in a manner that would be more palatable to his colleagues. Soon thereafter, Continental applied for a much larger area, now over 1000 square miles, which coincidentally encompassed the richest swath of spruce in the "Spanish Reserve".

From there it seemed practically predetermined that IP's subsidiary would acquire this pulpwood concession. The UFO insisted on tendering the timber tract, but then allowed Continental's officials to write the terms under which it would be sold. Predictably, the conditions stipulated that the winning bidder must build a kraft pulp mill within short order, a condition that practically precluded Spanish River, a newsprint-maker, from having a chance to acquire this wood. Over the course of mid-1923, even though there was an election campaign underway and the UFO was busy waging it and addressing other matters, Bowman found the time to execute a lease with Continental to this timber. The minister even went so far as to sign the contract with IP's subsidiary two weeks after his party had lost the election!

While there were many peculiar aspects to this affair, one of the most unusual dealt with the trees in question. IP's subsidiary had insisted that the tender for this wood require the winner to make kraft pulp, which is made from jack pine, not spruce. This meant that IP did not need even a single stick of the latter species of timber from the Spanish Reserve, and yet the Ontario government had literally given IP a huge belt of spruce that was desperately sought by Spanish River, IP’s greatest rival.

Furthermore, the Ontario election of 1923 saw the UFO go down to defeat to the Conservatives, a party that was now led by Howard Ferguson. As premier, he had a golden opportunity to show that he was indeed the greatest ally of Ontario's newsprint industry. He could have punished Continental by taking back the wood the UFO had given it and awarded it to Spanish River. Moreover, there was even more reason to do so over the next few years when IP did little to begin building the mill its contract with the government obliged it to construct. Instead, Ferguson allowed the firm to retain its lease and even granted it more resources under extraordinarily generous terms. Incidentally, Continental would never build its mill (it would not even dig the foundation for the plant!), and yet it would be permitted to hold onto this tract of timber for the better part of fifteen years.

For Spanish River, it was literally left picking up the pieces. Ferguson's government finally gave it a lease to a supplementary wood supply in late 1923 , but when this occurred the concession hardly resembled the one he had set aside for it four years earlier; its size and volume of spruce had shrunk by over one-third. Making matters worse was the fact that the limit would be inordinately expensive to operate because the largest chunk of it was farthest from its mill and the closest part in the south was broken up into a number of small blocks. In the end, Spanish River's mill in Espanola had gained enough spruce to last it only another roughly 27 years.

The astounding part was that Spanish River would suffer a practically identical fate a few years later at another of its newsprint-making facilities, this one at the Lakehead in the far northwest. Again on that occasion, the Ontario government would give IP a major tract of pulpwood that Spanish River desperately needed even though 
IP did not operate a local mill that could even have processed the timber. That story, however, awaits another day.

Ultimately, this snippet about the forest history in the environs of Espanola demonstrates a few important lessons to those who wish to venture into this field. The first is the need to follow any story through to its conclusion in order to flesh out all its details. Doing so is the only way to understand fully the actions taken by both govern- ment and industry. Moreover, this tale underscores that it is essential to be intimately familiar with the resources about which one is writing. Knowing which species of trees are used to make specific forest products is crucial knowledge for those who chronicle the roots of our pulp and paper industry. Adopting these approaches will greatly increase the chances that the historian who writes about the sale of Crown timber will interpret those transactions through a lens that is as free from distortion as possible.

[This article is based on a small part of the story Mark Kuhlberg tells in his new book, In the Power of the Government: The Rise and Fall of Newsprint in Ontario, 1894-1932. Members of the CIF/IFC are able to obtain a copy from the University of Toronto Press at a reduced rate.]

\section{NATIONAL/NTERNATIONAL NEWS ` NOUVELLS NATIONALES/INTERNATIONALES}

\section{Canadian Forestry Accreditation Board Annual Report - 2014}

$\mathrm{T}^{\mathrm{h}}$

he Canadian Forestry Accreditation

Board (CFAB) is responsible for the assessment of Canadian university forestry degree programs for the purpose of meeting academic requirements for professional certification (registration/licensure). Its role is to implement a national accreditation process mandated under a detailed Policy Statement agreed to by its member agencies, the eight professional forester/forest engineer associations of Canada, and the Canadian Institute of Forestry/Institut forestier du Canada. Board members are appointed by the member agencies.

Established in 1989, the Board has been conducting site visitations since 1990. Assessment of academic program is undertaken in accordance with comprehensive academic standards but includes, also, consideration of facilities and services offered; faculty experience, qualifications and tenure; and the ability of the program to imbue professional qualifications and qualities in students. The regular accreditation cycle for a program is six years, although circumstances may dictate a shorter period for a given program or an interim review to confirm that a program continues to meet accreditation requirements. At present, ten baccalaureate level and two Master's level forestry programs in Canada enjoy accredited status. The Board does not accredit faculties or institutions, nor does it review programs outside Canada.

During the year, the Board conducted an out-of-schedule program review, at the Faculty of Forestry, University of Toronto, of the school's Master of Forest Conservation Program. The site visit and review were undertaken by a team comprised of Faye Johnson, R.P.F., Peter Marshall, R.P.F. and Bruce Dancik, R.P.F. It was the first review by the Board of a University of Toronto

program since the demise of the longstanding undergraduate forestry program at the Faculty in the 1990s.

There were no regular site visits scheduled for the year. The fifth round of accreditation reviews will begin in 2015 with regular schedule visits to Universite Laval and the University of

\section{Status of CFAB Program Accreditations at Canadian Schools of Forestry} - December 2014

\begin{tabular}{|c|c|c|}
\hline Sept. 2009 & $\begin{array}{l}\text { Laval University, Faculty of Forestry, Geography and } \\
\text { Geomatics, Forest Management and Environment Program } \\
\text { and Forest Operations Program }\end{array}$ & $\begin{array}{l}\text { Accredited for six years } \\
\text { to June } 30,2015\end{array}$ \\
\hline Sept. 2009 & $\begin{array}{l}\text { University of Northern British Columbia, College of Science } \\
\text { and Management, Ecosystem Science and Management } \\
\text { Program, Forest Ecology and Management Major }\end{array}$ & $\begin{array}{l}\text { Accredited for six years } \\
\text { to June } 30,2015\end{array}$ \\
\hline Sept. 2011 & $\begin{array}{l}\text { University of New Brunswick, Faculty of Forestry and } \\
\text { Environmental Management, Forest Ecosystem } \\
\text { Management Program }\end{array}$ & $\begin{array}{l}\text { Accredited for six years } \\
\text { to June } 30,2017\end{array}$ \\
\hline Sept. 2011 & $\begin{array}{l}\text { University of Alberta, Faculty of Agricultural, Life and } \\
\text { Environmental Sciences, Alberta School of Forest Science } \\
\text { and Management, Forestry Program and Forest Business } \\
\text { Management Program }\end{array}$ & $\begin{array}{l}\text { Accredited for six years } \\
\text { to June } 30,2017\end{array}$ \\
\hline Sept. 2012 & $\begin{array}{l}\text { University of British Columbia, Faculty of Forestry, Forestry } \\
\text { Program, Forest Resources Management and Forest } \\
\text { Operations Majors }\end{array}$ & $\begin{array}{l}\text { Accredited for six years } \\
\text { to June } 30,2018\end{array}$ \\
\hline Sept. 2012 & $\begin{array}{l}\text { Lakehead University, Faculty of Natural Resources } \\
\text { Management, Forestry Program (H.B.Sc.F.) }\end{array}$ & $\begin{array}{l}\text { Accredited for six years } \\
\text { to June } 30,2018\end{array}$ \\
\hline Sept. 2013 & $\begin{array}{l}\text { University of Moncton, School of Forestry (formerly } \\
\text { Faculty of Forestry), Forest Sciences Program }\end{array}$ & $\begin{array}{l}\text { Accreditation extended } \\
\text { for three years to } \\
\text { June } 30,2016\end{array}$ \\
\hline Sept. 2013 & $\begin{array}{l}\text { University of British Columbia, Faculty of Forestry, } \\
\text { Master of Sustainable Forest Management Program }\end{array}$ & $\begin{array}{l}\text { Accredited for six years } \\
\text { to June } 30,2018\end{array}$ \\
\hline Sept. 2014 & $\begin{array}{l}\text { University of Toronto, Faculty of Forestry, } \\
\text { Master of Forest Conservation }\end{array}$ & $\begin{array}{l}\text { Accredited for six years } \\
\text { to December } 31,2019\end{array}$ \\
\hline
\end{tabular}

P.L. Marshall, R.P.F., Chairman, L.F. Riley, R.P.F., (Ret.) Executive Director 